\title{
A Body to Make Luanda: The Black Woman from the Countryside in Angolan Literature
}

\author{
JÚLIA GARRAIO \\ Universidade de Coimbra
}

\begin{abstract}
In this article, I examine how the image of the black woman from the countryside who moves to Luanda was developed at three key moments in Angolan literature as a means of constructing national identity. I focus on three prose works: Alfredo Troni's Nga Mutúri (1882); António Cardoso's short story "Linda," from A Casa da Mãezinha (1980); and Fragata de Morais's short story “Martinha," from Momento de Ilusão (2000).
\end{abstract}

Keywords: Alfredo Troni; António Cardoso; Fragata de Morais; Gender; lieux de mémoire

In this article, I examine how the image of the black woman from the countryside who moves to Luanda was developed at three key moments in Angolan literature as a means of constructing national identity. ${ }^{1}$ My analysis focuses on the following works, all of which participated in the construction of Luanda as an Angolan lieu de mémoire: Nga Mutúri (1882), a novella by Alfredo Troni about mestiço Luandan society in the second half of the nineteenth century; "Linda," a short story from A Casa da Mãezinha, by António Cardoso, an emblematic work

\footnotetext{
${ }^{1}$ This article results from the project "De S. Paulo de Luanda a Luuanda, de Lourenço Marques a Maputo: capitais coloniais em tempos pós-coloniais" (PTDC/CLELLI/122229/2010 - FCOMP-01- 0124-FEDER- 019830), which was financed by Fundos FEDER through the Programa Operacional Factores de Competitividade and by the Fundação para a Ciência e a Tecnologia.
} 
of anti-colonial literature that was written in 1962 from within a PIDE prison; and "Martinha," a short story by Fragata de Morais from Momento de Ilusão (2000), which takes us to the last years of the civil war and to the city's demographic explosion as a refuge sought by those displaced by the conflict.

\section{From where do we see Luanda?}

The flight from the countryside to the city as a driving force for profound personal transformation is a recurrent motif in literatures that deal with processes of urbanization, migration, and war. In the case of Luanda, this acquires certain particularities arising from the colonial roots of the city (its founding by the Portuguese in the sixteenth century; its growth as a hub for the trafficking of human beings and as a base for the expansion of Portuguese control in the region), from its role in the construction of Angolan nationalism, and finally, from its importance as the base for the MPLA to affirm its power over the country as well as the nerve center of the post-colonial state.

The emblematic places of Luanda, the events and historic figures, and the key legends of the city have been continually revisited by literature in the pursuit and (re)formulation of senses of nationhood and shared identity. Due to its centrality in the history of Angola, Luanda itself can justifiably be regarded as a powerful lieu de mémoire. ${ }^{2}$ To think of Luanda in this way obliges us to reflect on its people. In the nineteenth and twentieth centuries, the urban growth of the colonial city went hand-in-hand with the arrival of a wide range of individuals from the metropolis (government civil servants, deportees, settlers, and the military). However, the white population, despite being dominant in politicoeconomic terms and capable of imposing models of urban expansion, was always a minority in the city. It was above all black people, frequently from the more vulnerable social strata and from other parts of Angolan territory (slaves, migrants in search of work, war refugees), who formed the basis of the social fabric of the capital in expansion, making up 95\% or more of the city's population from 1900-74 (Bender 71).

\footnotetext{
${ }^{2}$ According to Pierre Nora, a lieu de mémoire (realm or site of memory) is "any significant entity, whether material or non-material in nature, which by dint of human will or the work of time has become a symbolic element of the memorial heritage of any community" (xvii).
} 
In a literature composed predominantly by men, the process of migration from the countryside to Luanda nonetheless centers, in many cases, on female protagonists. Although women have been a sector of considerable weight in subSaharan urban migrations (Coquery-Vidrovitch 124-48), this choice by Angolan writers is certainly motivated by the frequent use of female characters as a metaphor for the nation. In Angolan literature, there are well-known examples of this literary practice (see, for instance, the image of the mother in Agostinho Neto). While in relation to Africa, the predominant associations are with nature, tradition, and origins, the conversion of Luanda into metaphor tends to be less static and to represent this urban space as a site constructed upon (and sometimes precisely against) that reality. An encounter of distinct migratory flows, framed by a socio-political reality with origins in a colonial project, takes place there. For this reason, the perspective adopted in literary texts to represent the impact of the urban space upon the subject is geographically, racially, and politically situated, and is strongly determined by the complex relations of power within which this viewpoint is integrated and in which it participates.

The texts that form the basis of the present study exemplify the complexity of the narrative perspective and its fictional nature. If we focus on the identity of the characters, we might affirm that this study is about those for whom the city's urban planning was not designed (a slave, an economic migrant, and a refugee), but who comprised the raw material for the construction and expansion of the city, and who, arriving from the countryside, had "an outsider's" perspective of the space. If we divert our attention to the authors, however, we are then presented with a perspective "from within" and with links to the maritime side: an intellectual and political elite, whose power is anchored in Luanda and with (more or less distant) roots in the metropolis. The narrative voice deepens this complexity. The concept of an omniscient narrator does not signify, as we know, neutrality. Even though the narration is permeated in the three texts by the voice of the characters (or rather by what is defined in the narrative as the discourse of these characters), the narrators carry markers of masculinity and signs of the privileged sectors of Luanda's social fabric.

The gap between author, character, and narrator (in aspects such as gender, geographical origin, social class, racial identity, economic situation, and level of education) structures the texts, as we will see. The tensions caused by these disconnections enable what at first glance seems to be an attempt by the authors 
to translate strange experiences, thereby aiming to give voice to those who had no access to the literary word, to be understood rather as a pretext for the country's intellectual elite to imagine and reflect on the Angolan nation as a project of modernization. Through an analysis of the gender constructions that structure the narratives, I argue that the construction of an Angolan sense of nationhood in these texts relies on the authors' use of the female body as a material through which different forms of masculinity define themselves in a space founded by the violence of the colonial project.

\section{Something new on the west coast of Africa}

Alfredo Troni had been living in Luanda for ten years when his novel Nga Mutúri: Cenas de Luanda (1882) was published in the Diário da Manhã (Lisbon). Soon afterwards, it appeared in Jornal das Colónias (Luanda), and in this way it reached both readers from the metropole and the literate population of Angola. ${ }^{3}$ The narrative voice of the novella is markedly metropolitan, with the narrator acting as someone who, having access to a "strange" reality, makes it legible in his own culture by using numerous footnotes explaining linguistic expressions and local customs. This translatory process entailed conveying a visualization of the colonial space to a cultivated metropolitan readership. The process of appropriation of a "strange" culture by the colonizer becomes simultaneously a kind of birth certificate for that particular culture due to the affirmation, through literature, of its "separate" character.

It is worth bearing in mind the context in which the novella was produced, namely the flourishing Angolan press of the second half of the nineteenth century as a space for the development of writers and intellectuals, with various newspapers promoting local cultures and languages (Laranjeira 19; Macedo 91). In literary criticism, Nga Mutúri is valued as a foundational text, as a precursor of Portuguese-language Angolan literature and as the first attempt to apprehend the mixed world of habits and values from which what was later known as "Angolanness" was being built (Laranjeira 48; Chaves 36). In other words, the

\footnotetext{
${ }^{3}$ A native of Coimbra, where he studied law, Troni (1845-1904) arrived in Angola in 1873. He became a key figure in the intense journalistic and literary activity of Luanda. During this period, the readership of the Luandan press was made up of a minority of "assimilated" mestiços and blacks (António 14).
} 
analysis of the novella revolves frequently around the concepts of mestiço and creole culture as expressions of Luanda at the time. Historical research refers to the city as an example of an African urban space in which the prevalence of mestiços is intimately related to the city's slave-trading past and where a certain type of creole woman (some of whom were only culturally creole) acquired a privileged status through relationships with European men, and achieved notoriety as astute businesswomen (Coquery-Vidrovitch 92-98). It is easy to recognize this social context in the plot of the novella. However, if we read the text from a post-colonial perspective enriched by feminist studies on sexual violence (such as that offered by Higgins and Silver), that is, if we engage in an analysis that deconstructs the colonial attitude by disrupting and challenging the naturalization and concealment of sexual violence, Troni's novella unveils Luandan mestiçagem as a process built upon power relations forged through sexual violence and the sublimation of traumatic memories.

The association between pretense and forgetting as a pillar of the protagonist's integration in the urban fabric of Luanda is disclosed right at the beginning of the novella: "Ela, à força de afirmar que não foi escrava, esqueceuse de [não] ter sido sempre livre" (35). This effort of manipulating memory is immediately exposed as fragile. Sitting outside her house "nas noites de luar quentes e sossegadas," the protagonist is haunted by memories of the past, which prompt the extended flashback through which her life is narrated, from her childhood in the bush to her current status as Nga Mutúri, the Widowed Lady, a respected Luandan businesswoman (35). It is a journey of violence and acculturation in which the geographical destination, Luanda, plays a fundamental structuring role.

The protagonist's enslavement, to pay the debt of an uncle, is represented as the annihilation of her identity (see the death rituals observed on the eve of her departure, as well as how, upon being delivered to her white owner, her child's body is reduced to its materiality, stripped of any ornament, washed and embellished with new clothes). After being separated from her mother, the protagonist undergoes a process of uprooting in which sexual violence functions as a strategy of control and possession: "Ainda tem presentes os brutais sofrimentos todas as noites durante a jornada, e os dentes brancos que the mostrava o seu dono quando ela chorava e gemia" (39). This process is accompanied by an effort of acculturation through which the abused female body 
adopts, as a survival strategy, the cultural habits of the colonial oppressor (language, clothes, hairstyle, certain domestic chores). These are roles defined as feminine in the culture of the colonial power (domestic chores and sexual service) that support the promotional process facilitated by domestic slavery (António 24). In other words, the transformation of the character is based on a convergence between violence and sexuality, which functions as a pillar of colonial dominance and at the same time as a possibility of empowerment for the victim. It is sexual work that enables the protagonist to achieve the status of mucama (room maid and concubine) in her owner's home, replacing the former slave (who is sold to a slave ship). It is this same work that enables her, some years later, to accompany him to Luanda, where she becomes Nga Ndreza (Lady Andreza), and where she would inherit his property, thereby becoming the respected Nga Mutúri. Hence, although the body of the owner is represented as something repulsive, deformed by alcohol and illness, and a source of physical violence, it is simultaneously sexually sought after by the protagonist as a source of protection, above all in her failed attempts to get pregnant.

The appropriation of the sexuality of the black woman and the repression of her autonomy have wider social implications. As the brutal punishment of the protagonist due to her sexual adventures with an attractive slave unfolds, the supremacy of the white man demands not only the molding of the black female body as an object of domestic use, but also the neutralization of the sexuality of the black man. Sexuality in the Luandan space is represented in the novella as a private sphere that reflects and simultaneously constructs a web of power relations and colonial hierarchies to which the colonized themselves end up adhering. This is seen in the humiliation that the protagonist feels when she, a mucama Nga Muhatu (a common-law wife of a white man), is flogged like a black person with no special status (Troni 47).

The processes of assimilation through the body of the protagonist are situated as part of a specific geographical context: "Nga Ndreza conheceu então [em Luanda] o que era, e o que devia parecer. Esqueceu-se da primeira época da sua vida, e respondia com umas reticências duvidosas às perguntas que lhe faziam sobre a sua origem" (44). The city emerges as a space of social relations ruled by appearances and lies (the protagonist invents a white father to value herself socially as being mestiça), by interests (false friends, dishonest businesses) and where one's social life is characterized by excessive consumption of food and 
alcohol. It is a world of dangers and of fragile identities, in which social positions are granted by the correct execution of certain rituals, as the protagonist soon realizes: she performs to perfection the funeral rituals, maintains the appearances demanded of her, pays her taxes, and gives presents to the right people.

The various references to the toponymy of Luanda-Ngombota, Nossa Senhora de Muxima, Calçada do Carmo, Musseque do Spínola-despite not being followed by detailed depictions of these urban spaces, are crucial in order to give meaning to the sociocultural processes portrayed. The urban space emerges as subjective experience, as impact, as an effect on the individual that culminates in the acceptance, by the colonized, of the culture of the colonizer: "E como a experiência da vida vai bem, e compara a sua existência na libata com a que leva agora, diz de si para si que a terra do Muene Putu é muito melhor que o mato" (85). Nga Mutúri emerges in this way in the novella as a symbol of Luandan mestiço society which, adhering to the cultural codes of the colonial oppressor, pushes itself to forget the roots of the acculturation process, namely slavery and sexual violence as the pillars of the existing social order. The mestiçagem that Troni presents in the novel is grounded in the subjugation of one migrational flow by another, a process in which the molding of the black female body by white male sexuality is a cornerstone.

\section{The awakening of anti-colonial masculinity}

The Luandan mestiço society of the last decades of the nineteenth century saw its power and relative autonomy increasingly threatened by the centralizing efforts of the metropole, which culminated in the Colonial Act of 1931. Progressively removed from the centers of power, this social class was replaced by white immigrants who deepened the segregation of the city: the asphalt areas were mainly white, whereas the black population was concentrated in musseques (shantytowns), neighborhoods of extreme poverty without basic infrastructure, which also housed many poor whites. Angolan anti-colonial nationalism emerges in this historical context in the second half of the twentieth century. It is grounded in an intense literary production, with Luanda appearing in the background of literary texts that aim to give artistic form to an African nationalist project and praise oppressed people in their pursuit of a national identity (Laranjeira 37-9; Macedo 114ss). As exemplified by the work of writers such as Agostinho Neto 
("Sábado nos musseques," “À Reconquista”), Luandino Viera (Luuanda), Jofre Rocha (Estórias do Musseque) and Boaventura Cardoso (Dizanga dia Muenhu) among many others, anti-colonial Angolan literature represents the asphalt city as the symbol of oppression and colonial exploitation, and turns instead to the musseque as a source of inspiration and as the site of the "people's soul." "The ideological struggle through the symbolic space takes place in the city of Luanda (and not through the country/city dichotomy), a trait that underlines the modern character of the anti-colonial project of creating a post-colonial state out of the colonial experience. This process is revealed in António Cardoso's A Casa da Mãezinha: Cinco Estórias Incompletas de Mulheres.

Cardoso was a white Angolan journalist and writer, imprisoned for several years in the Tarrafal prison camp in Cabo Verde. ${ }^{5}$ Written in 1962-63, during Cardoso's imprisonment in Luanda, A Casa da Mãezinha represents the colonial situation through a border space: a brothel between the musseque and the asphalt, where the clientele is mainly white and mestiço collaborators of the colonial system, the prostitutes are black women and mestiço daughters of absent white fathers, and the musicians are Cabo Verdean. At a time when the Portuguese state used Lusotropicalist discourse as a propaganda weapon to justify Portuguese control over its African colonies, Cardoso revisits a cornerstone of that discourse-sexual encounters between whites and blacks - to represent it as oppression, exploitation, and violence from one side (white male/Portugal) toward the other (black female/Angola). His work validates the words of Pinto regarding the reification of women, reduced to sexuality at the service of the colonizer, as the basis of Lusotropicalism (Pinto 37).

"Linda," the third story of the volume, offers a greater problematization of the Luandan public spaces. The protagonist is a black woman from the countryside named Ndémbu, whose social fragility there made her seek the city looking for entertainment and a better future. In her initial contact with Luanda, the ambiguity of the space unveils itself before the protagonist, who, faced with something seen as overwhelming, oscillates between wonder and fear. The experience of the city is marked by strangeness and a process of acculturation,

\footnotetext{
${ }^{4}$ Macedo uses the term prosa do musseque to designate Angolan engaged literature from the 1950s to the 1980s (Macedo 122).

${ }^{5}$ An MPLA militant, Cardoso worked for the National Radio, the Secretary of State and Culture, and the Angolan Writers' Union after Angola's independence.
} 
which is expressed in the annihilation of her former identity (she changes her name and way of dressing, learns new dances and social habits) and her insertion in a social order ruled by segregation:

Conheceu todos os recantos de Luanda. Era bela. Na Baixa, então, havia uma sedução especial. Parecia-lhe que saía de um mundo condenado, feio e sujo, para outro cheio de luz, cor, movimento: era mesmo outra terra. . . . Então, ouvia o "Senhor Padre" muito zangado falar no pecado das pessoas. Devia ser verdade. Toda a gente do Musseque era pecadora e deus, então, tinha-lhes dado aquele destino abandonado. Era mesmo por isso que as ruas não tinham alcatrão nem candeeiros, só havia mesmo montes de lixo, porcaria, moscas, e não havia comida para todas as pessoas. (68-69)

The city as a space of well-being is denied to her. She is only permitted to live in the musseque and move in disadvantaged places that are associated with penury, waste, and the menial work that is necessary for the functioning of the city: "Passados dias foi trabalhar no Mercado Indígena, o Mercado do Xa-Mavu ... Trabalho sujo daquela maneira: haka! tanta mosca, tanta porcaria no chão! ... As outras ralhavam: menina tem que se habituar, não liga nas moscas. À noite, banhava-se com frenesim, para tirar aquele cheiro teimoso" (67).

This moment anticipates the degradation of her body and its submission to disgust, which culminates in the brothel, after her failed attempts to make a living from domestic work and commerce. Having been used as a disposable "working tool" in an economy ruled by whites, the black female body becomes an object of sexual work for the same sector of the population.

Cardoso's text, like Troni's novella, gives visibility to the role of the black body as material for the colonial project. However, while in the novella this process offers the possibility of social ascension, in the anti-colonial text it is represented exclusively as exploitation. Unlike Nga Mutúri, who achieves a privileged status in Luanda by molding her body to the colonial project, with Linda the same paths are nothing but traps that lead to degradation. Work for the local economy and the subordination of black female sexuality to the racial hierarchy that rules the social life of the colony destroy Linda's beautiful body and progressively distance her from the desired social integration. 
Despite this dysphoric representation of the impact of the city on women from the countryside, Cardoso's text does not engage in any kind of nostalgia for a "paradise lost." The volume relies on the awareness of the irreversibility of colonial heritage, proposing in turn its overcoming through something new and modern that is personified by the student, a character who appears in the next story ("Maria") imbued with messianic traits (a common procedure in anticolonial literature). Unlike the clients who function as mediators of the narrative perspective in the first three stories (whites and a mestiço who benefit from the colonial system), all of them cynical exploiters of women's bodies, the student appears as redemptive masculinity. It is upon him (and in the subversive activities he organizes from the brothel) that the hope of a future of liberation relies, one that dignifies the bodies subjugated and deformed by sexual exploitation. Anticolonial liberation is hence metaphorically represented by specific gender constructions: a people, symbolized by women exploited by a violent colonial masculinity, who would be dignified by an emergent revolutionary and anticolonial masculinity, whose strength resides in intellect and moral integrity. The construction of the desired post-colonial nation takes place in the colonial space, having as protagonist a masculinity that is also rooted in the colonial city, which, as happens with the asphalt/musseque dichotomy, contains in itself the possibility of its own overcoming. Luanda emerges as a space of colonial oppression but also as a place for the emergence of African national emancipatory awareness.

\section{The collapse of the masculinity forged in the anti-colonial struggle}

The national independence longed for by writers committed to the anti-colonial struggle came with a post-colonial state ravaged by a long war, constant foreign interference, and a social fabric characterized by deep economic inequality. Those displaced by the civil war flooded the poor neighborhoods of Luanda and the city's streets, and they remain the most painful reminders of the unfulfilled revolution, of the limitations and failures of the project dreamed for by the anticolonial struggle. In Angolan literature of recent decades, there have been several attempts to portray the fate of children and adolescents who sought Luanda as a safe haven and who were condemned to abject poverty and subjected to repeated violence. We may take as examples Roderick Nehone's $O$ Ano do Cão (1999); the poem "Novembro sem água" (1999) by Paula Tavares; Fragata de Morais's 
short story "Martinha" (Momento de Ilusão, 2000); and the short stories "Tio me dá so cem" and "Feto" (Filhos da Pátria, 2001) by João Melo. Emblematic places of the city (the Isle, the central avenues, and squares such as the Largo da Mutamba) tend to appear in these texts from "an outsider's" viewpoint, that is, from the perspective of those who have no right to occupy these places and can only be there temporarily by resorting to strategies punishable by law (street trading, robbery, prostitution). Given this, they are under continuous threat from the police. The urban space is hence represented essentially as a space of exclusion and danger for those who are socially most vulnerable.

The short story "Martinha" takes up motifs from Nga Muturi and "Linda" through a common figure in the imaginary of post-colonial Luanda: the adolescent prostitute. The plot is simple: Serafim, a white Angolan journalist old enough to be a grandfather, well-positioned in Luandan society (a character who shares many traits with the author) is approached on the beach of the Ilha by two girls aged twelve and fourteen, war orphans from Malanje. ${ }^{6}$ Having been initiated into sexual activity on their journey to Luanda by members of the international peacekeeping force (UNAVEM), they survive in the city as prostitutes in search of foreigners who might take them, albeit temporarily, from the streets where they are vulnerable to robbery and sexual abuse by the police and street boys, who control what shelter there is (dumpsters, public benches). The objective of both girls is, ironically, the situation of Nga Muturi: to live in the house of an older, white man (preferably Portuguese) in exchange for sex and domestic work.

"Martinha" is probably one of the most radically dysphoric depictions of Luanda, which becomes even more striking if we consider her literary predecessors: Nga Muturi inherits her owner's property; Linda is relegated to the musseque, where she comes across a redemptive masculinity. Martinha and her sister, on the other hand, have no place in Luanda, they move in temporary spaces where they are only able to remain as long as men find their bodies of use. Reduced in this way, they experience Luanda through its transitory spaces, the so-called non-places-streets, public benches, or a public beach. They experience the city as a space to which they have no right.

\footnotetext{
${ }^{6}$ Fragata de Morais (Uíge, 1941) studied theater and cinema in Paris and Amsterdam in the 1960s and 1970s. Along with his literary, journalistic, and cultural activities, he has a successful career in diplomacy and politics. He is a former member of parliament for the MPLA and vice-minister of Education.
} 
The misery of Morais's two girls has a specific politico-economic context: "Um helicóptero da companhia nacional sobrevoou o local, em direção ao norte, aos campos da milionária miséria angolana" (66). Such statements stress the role of refugee literature in denouncing the asymmetries of the post-colonial Angolan state. However, in this reflection, the girls are above all an instrument for the other character in the story, Serafim, to acknowledge a social substrate that exists behind the façade of cosmopolitan and wealthy Luanda. Hence the focus of the text is driven to a masculinity situated in the city. Deeply shocked, Serafim wants to send Martinha and her sister to state institutions or charities; however, the girls have been so thoroughly traumatized by war and sexual exploitation that they do not believe that anyone can offer them anything without demanding sex. In order to give meaning to what they do not understand, they activate a magical vision of the world that they brought from Malanje: "Esses bragas angolanos também são feiticeiros, e tudo nele indicava isso. Lembravam-se de ter ouvido, com espanto e maravilha, os velhos lá na aldeia contar como os soldados cubanos haviam engravidado os homens de Malange" (68).

Impotent, Serafim sees the girls moving away in suspicion. He returns to reading, unable to bridge the gap that separates him, as a member of the Luandan cultural elite, from the marginalized, abused, and exploited population of the interior, which remains tied to a world of superstition.

Bearing in mind the author's position as a member of the Angolan cultural elite, his literary alter ego's impotence can be read as the collapse of anti-colonial masculinity forged in the independence struggle and as part of the modernization project of the MPLA. Bauman defined the construction of modern states as processes of standardization and the imposition of politico-economic projects to specific territories, which were normally accompanied by violence causing numerous victims. This analysis, though it refers principally to European states, helps to understand the tensions characteristic of numerous states created out of anti-colonial movements. Both the analyses of the Angolan Civil War that focused on ethnic differences (Chiadjeu) and those centered on the ideological ruptures within independence movements (Mabeko-Tali) converge in the concept of competing national projects, each with potential for unavoidable exclusion. The construction of post-independence Angola can be defined as the creation and imposition of an imported model of state the MPLA aimed to extend to the entire Angolan territory from their base in Luanda. This modernist project 
contained a discourse that rejected everything obscurantist or tribal, a prejudice that encouraged the gap between the political elites of Luanda and the rural popular masses and their leaders (Mabeko-Tali 235).

In a metaphorical way, "Martinha" depicts the epiphanic encounter between an actor of this modern national project and a "collateral" victim of its imposition, an encounter whose significance is not apprehended by the subaltern, but which has devastating consequences for the post-colonial actor, confronted with the disconnect between an intellectuals based in Luanda and the marginalized populations of the interior-with a deep gulf between the elite and the marginalized classes of the post-colonial state. Ultimately, the story depicts the collapse of the dream of the Angolan nation that writers like Cardoso had longed for: the dream of a union between the intellectual elite formed in Luanda and the exploited masses in the construction of a just nation.

\section{Conclusion}

By analyzing texts that represent key phases in the evolution of Angolan literature, I have examined how the black female body, subjected to uprooting experiences, exploitation, and violation in Luandan urban spaces, was successively used by the male intellectual elite to represent the social fabric of Luanda and the (emergent) Angolan nation. Sexual violence gains centrality, not as a side effect of social conflicts, but as a fundamental strategy in the construction and maintenance of social order and hegemonic masculinity. Sexual submission, which in Nga Muturi functions as a disciplinary method of indigenous bodies and as a means of access to social integration, becomes, in anti-colonial literature, a metaphor for the degradation of the local population in the colonial order. In the literature about refugees this motif is used to represent the failure of the post-colonial state.

Without embarking upon any nostalgia for pre-colonial Africa, the examined texts represent Luanda-the city driving the nation-as a site of violent encounters between races and sexes. It is a multiracial space of mestiçagem, but one that invalidates any kind of Lusotropicalist discourse, since the Angolan mestiço identity forged in Luanda is always portrayed as resulting from violence and power relations marked by inequality and sexual abuse.

\section{Works Cited}


António, Mário. "Prefácio.” Nga Mutúri, by Alfredo Troni. Lisbon: Edições 70, 1991. N.p. Print.

Baumann, Zygmunt. Wasted Lives: Modernity and its Outcasts. Cambridge: Polity, 2004. Print.

Bender, Gerald J. Angola sob o domínio português: mito e realidade. Luanda: Nzila, 2009. Print.

Cardoso, António. A casa da mãezinha: cinco estórias incompletas de mulheres. Lisbon: Ulmeiro; Luanda: Inald, 1980. Print.

Chaves, Rita. A formação do romance angolano. São Paulo: Via Atlântica, 1999. Print.

Chiadjeu Jamfa and Léonard Moïse. Comment comprendre la “crise” de l'État postcolonial en Afrique? Bern: Peter Lang, 2005. Print.

Coquery-Vidrovitch, Catherine. Les Africaines. Histoire des femmes d'Afrique subsaharienne du XIX au XX siècle. 1994. Paris: La Découverte, 2013. Print.

Higgins, Lynn A. and Brenda R. Silver, eds. Rape and Representation. New York: Columbia UP, 1991. Print.

Laranjeira, Pires. Literaturas africanas de expressão portuguesa. 1995. Lisbon: U Aberta, 2005. Print.

Mabeko-Tali, Jean-Michel. Barbares et citoyens: l'identité nationale à l'épreuve des transitions africaines. Paris: L'Harmattan, 2005. Print.

Macêdo, Tânia. Luanda, cidade e literatura. São Paulo: Nzila, 2008. Print.

Nora, Pierre. Realms of Memory. 3 vols. Trans. Lawrence D. Kritzman. New York: Columbia UP, 1996-98. Print.

Morais, Fragata. Momento de ilusão. Porto: Campo das Letras, 2000. Print.

Pinto, Alberto Oliveira. "O colonialismo e a 'coisificação' da mulher no Cancioneiro de Luanda, na tradição oral angolana e na literatura colonial portuguesa." A Mulher em África. Ed. Inocência Mata and Laura Padilha. Lisbon: Colibri, 2007. 35-49. Print.

Troni, Alfredo. Nga Mutúri, Lisbon: Edições 70, 1991. Print. 